\title{
Influence of Chemical Structure of Petrochemical Polyol on Properties of Bio-polyurethane Foams
}

\author{
Aleksander Prociak ${ }^{1}$ - Leonard Szczepkowski ${ }^{2} \cdot$ Joanna Ryszkowska $^{3} \cdot$ Maria Kurańska $^{1} \cdot$ Monika Auguścik $^{3}$. \\ Elżbieta Malewska ${ }^{1} \cdot$ Michał Gloc $^{4} \cdot$ Sławomir Michałowski $^{1}$
}

Published online: 19 July 2019

(c) The Author(s) 2019

\begin{abstract}
In this study, the influence of the chemical structures of petrochemical polyols on the foaming process of polyurethane compositions as well as on selected properties of the foams obtained has been investigated. Two types of petrochemical polyols were used-polyester and polyether polyols as well as their blends with a rapeseed oil-based polyol. Dielectric polarization, temperature and expansion velocity were determined during the foaming process of the polyurethane systems with different polyol components. The results show the highest reactivity of the polyester polyol and a decrease of the polyurethane system's reactivity as a result of a partial replacement of the petrochemical polyol with the bio-based polyol. The content of the closed cells in the materials obtained strongly depends on the petrochemical polyol used. The results indicate that the chemical structure of the petrochemical polyol had a significant effect on the cellular structure as well as the physicalmechanical properties of the final products. A significant worsening of the foams' mechanical properties was observed as an effect of a partial replacement of the polyester polyol with the rapeseed oil-based polyol. In contrast, a partial replacement of the polyether polyol caused an improvement of the cell structure keeping the mechanical properties of the modified foams at the same level.
\end{abstract}

Keywords Polyurethane foams $\cdot$ Mechanical properties $\cdot$ Thermal properties $\cdot$ Cellular structure $\cdot$ Bio-materials, biopolyols

\section{Introduction}

Research institutions and industry undertake efforts to make chemical production more eco-friendly and to replace fossil raw materials with renewable feedstock [1]. More and more research concerns modification of polymers with waste

Maria Kurańska

mkuranska@chemia.pk.edu.pl

1 Department of Chemistry and Technology of Polymers, Cracow University of Technology, 24 Warszawska, 31-155 Cracow, Poland

2 FAMPUR Adam Przekurat Company, 40/30 Gersona, 85-305 Bydgoszcz, Poland

3 Faculty of Materials Science and Engineering, Warsaw University of Technology, 141 Wołoska, 02-507 Warsaw, Poland

4 University Research Centre Functional Materials, Warsaw University of Technology, 141 Wołoska, 02-507 Warsaw, Poland
[2-6]. Among the renewable raw materials, vegetable oils are the most widely used in the synthesis of different chemicals, which could be applied by the polymer industry $[7,8]$. In the case of polyurethane (PUR) synthesis, the idea of a substitution of petrochemical-derived feedstocks with plant oil-based components is increasingly developed.

Currently, PURs are widely used in industry and daily life due to their versatile properties $[9,10]$. It was estimated that PUR demand will grow from 14.2 million tons in 2011 to 22.2 million tons by 2020 . PURs are currently the sixth most widespread group of polymers [11, 12]. PURs are most often used in the furniture, automotive, footwear, construction and refrigeration industry. There are multiple applications in which they appear as foamed materials. These types of materials may be in the form of flexible, semi-rigid and rigid foams. Foams are divided also into categories depending on their pore morphology (open or closed). The open cell morphology corresponds to pores that are connected to each other, making the material softer and more absorbent. 
In the closed cell morphology, pores are isolated from each other, which makes the foam more rigid.

Bio-based polyols may be synthesized from different plant oils, such as rapeseed, sunflower, soybean, palm, linseed and castor oil [13-16]. A modification of vegetable oils in order to introduce reactive hydroxyl groups can be carried out by means of various methods. These methods are mostly based on the conversion of double bonds into hydroxyl groups [17] or transesterification and transamidization reactions [18-21]. The structure of a bio-polyol, viscosity, molecular weight and hydroxyl value have a significant impact on the foaming process of a PUR system and consequently on the cellular structure and properties of PUR foams [22]. Bio-polyols obtained from vegetable oils are composed of fatty acids. Bio-polyols may contain in their structures hydroxyl groups located inside the main hydrocarbon chain and dangling chains. Such secondary hydroxyl groups have a low reactivity and can lead to incomplete cross-linking of the PUR matrix $[14,23]$. The primary group located at the end of the hydrocarbon chains, like in the petrochemical polyols, has the greatest ability to react with iscocyanates. However, the two-step method of oil epoxidation and oxirane ring opening typically results in bio-polyols having lower reactivity than polyols obtained using such techniques as ozonolysis, hydroformylation or ethoxylation due to secondary hydroxyl groups [24]. The regions where dangling chains are located do not support stress when the sample is loaded and act as a plasticizer that reduces the rigidity of the polymer matrix $[14,23]$.

The use of bio-polyols in the synthesis of rigid PUR foams changes a number of physical and mechanical properties. It has been observed that an addition of a bio-polyol reduces the reactivity of the system, resulting in lower temperatures in the foam's core and slower foam growth. The lower reactivity of the foams modified with bio-polyols has an influence on the cellular structures of the final foamed products. It has been noticed that a replacement of a petrochemical polyol with bio-polyols can decrease the content of closed cells [25]. A closed cell structure is demanded for foams applied in thermal insulation, while an open cell structure is important for rigid porous materials, which are used as pumice stones. Other properties that may be changed by an addition of a bio-polyol are: apparent density, compressive strength, bending strength, brittleness, thermal conductivity.

Taking into account more and more studies focused on the modification of PURs with bio-polyols, it is necessary to analyze how such bio-components can influence the properties of the final foams, especially in different configurations with petrochemical polyols. A large number of published papers is mostly focused on describing the bio-polyol's chemical structure and its influence on the properties of porous materials. This paper investigates the influence of

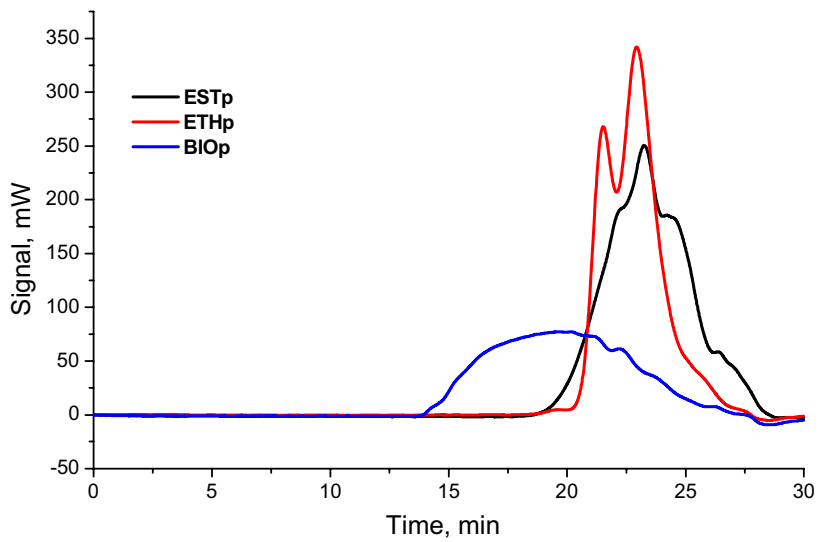

Fig. 1 The chromatograms of the polyols obtained using gel permeation chromatography (GPC)

Table 1 The characteristics of the polyols used in the synthesis of the PUR foams

\begin{tabular}{llll}
\hline Property & ETHp & ESTp & BIOp \\
\hline OH** $(\mathrm{mgKOH} / \mathrm{g})$ & 420 & 420 & 266 \\
$\mathrm{Mn} * *(\mathrm{~g} / \mathrm{mol})$ & 428 & 327 & 1788 \\
$\mathrm{Mw}^{* * *}(\mathrm{~g} / \mathrm{mol})$ & 625 & 739 & 10459 \\
Dyspersity & 1.46 & 2.26 & 5.85 \\
Functionality & 3.20 & 2.45 & 8.48 \\
Content of water $(\mathrm{wt} \%)$ & 0.10 & 0.10 & 0.40 \\
\hline
\end{tabular}

*OHv—hydroxyl value; **Mn—number average molar mass; *** $\mathrm{Mw}$-weight average molar mass

a rapeseed oil-based bio-polyol in configuration with two types (polyether and polyester) of petrochemical polyols on the foaming process and physical-mechanical properties of rigid PUR foams. For the first time, the effects of the blends of the same bio-polyol with different types of petrochemical polyols on foam quality have been compared.

\section{Experimental}

\section{Materials}

Polyether polyol (ETHp) and polyester polyol (ESTp) components with different chemical structures were used as petrochemical components. A bio-polyol (BIOp) was synthesized using a two-step method: epoxidation of the double bonds of a rapeseed oil and reaction of opening oxirane rings by using diethylene glycol [26]. The characteristics of the polyols used are shown in Fig. 1 and Table 1.

The broad peak of BIOp is associated with oligomerization side reactions that occurred during the ring opening reactions. This effect is also confirmed by a higher 
number average molecular weight (Mn) of BIOp comparing to the petrochemical polyols ETHp and ESTp. The effect of the oligomerization reaction is also reflected by the highest functionality of BIOp. Those reactions occurred when the hydroxyl derivatives of the rapeseed oil reacted with other epoxy groups during the second step of the reaction (oxirane ring opening).

An amine reactive catalyst was used in order to reduce the emission of a volatile organic compound from the foamed products. A special silicone surfactant was applied to improve the emulsification of the polyol premix, to ensure opening of cells in a final stage of the foam rise and to stabilize the porous structure of the foams. The carbon dioxide generated during the foam growth process in the reaction of water with isocyanate groups was used as a chemical blowing agent. A mixture of methylene diphenyl diisocyanate (MDI) isomers and oligomeric MDI containing $32.6 \mathrm{wt} \%$ of NCO groups was used as an isocyanate component.

\section{Preparation of the Foams}

Firstly, rigid PUR foams with different petrochemical components (ETHp and ESTp) were prepared. In the second step, both formulations were modified by replacing the petrochemical polyols (50 wt $\%$ ) with the bio-polyol (BIOp). The foams were prepared using a one-step method from two component systems (component $\mathrm{A}$ and component B). The formulations of the materials obtained are shown in Table 2.

Component A (polyol premix) consists of polyols, a catalyst, water and a surfactant which were mechanically stirred for $20 \mathrm{~s}$ to ensure their complete homogenization. After that, the isocyanate (component B) was added to the polyol premix in such an amount that ensured the ratio $\mathrm{NCO} / \mathrm{OH}=1.06$ (the contributions of the polyols and water were considered in the $\mathrm{OH}$ calculation). Next, the mixture of components A and B was mechanically stirred for $10 \mathrm{~s}$ and poured into an open mold. In the mold, a free rise foaming process took place.

\section{Characterization of Bio-polyols}

The determination of hydroxyl value was performed according to the Standard PN-93/C-89052/03, in which the hydroxyl groups of a polyol undergo acetylation using acetic anhydride. The excess of the acetic anhydride is decomposed by water addition (formation of acetic acid) and followed by titration using a solution of potassium hydroxide in the presence of an indicator.

The number and weight average molecular weight and dispersity were determined by GPC analysis. The measurements were performed using a Knauer chromatograph equipped with a PLgel MIXED-E column for the analysis of oligomers and a refractometric detector. The calibration was performed using the polystyrene standards. Tetrahydrofuran was used as an eluent at $0.8 \mathrm{~mL} / \mathrm{min}$ flow rate at room temperature. The number-average functionalities of the polyols were calculated based on the hydroxyl values and the experimentally determined number-average molecular weight (Eq. 1):

$\mathrm{fn}=(\mathrm{Mn} \cdot \mathrm{OHv}) / 56110$

where, fn-number-average functionality, $\mathrm{Mn}$-numberaverage molecular weight and $\mathrm{OHv}$-hydroxyl value of polyol.

\section{Characterization of Polyurethane Foams}

The foaming process was analyzed using the foam qualification system FOAMAT [25]. The content of closed cells was determined according to PN-EN ISO 4590:2005. The apparent density was determined as a ratio of the mass and volume of the foam sample according to a standard (ISO 845:2010).

The cell structures of selected foams were tested using computer microtomography. The study was performed using a CT scanner Xradia 410CT [27].

The mechanical properties of the foams were estimated in two directions, parallel and perpendicular to the foam rise. The compressive strength was determined according to ISO 826. The compressive force was applied at a speed of $2 \mathrm{~mm} / \mathrm{s}$, axially in a perpendicular direction to a square
Table 2 The formulations of the foams prepared

\begin{tabular}{lllll}
\hline Raw materials (g) & PU/ETHp & PU/ESTp & PU/ETHp/BIOp & PU/ESTp/BIOp \\
\hline Polyether polyol (ETHp) & 100 & - & 50 & - \\
Polyester polyol (ESTp) & - & 100 & - & 50 \\
Bio-polyol (BIOp) & - & - & 50 & 50 \\
Amine catalyst & 2.25 & 2.25 & 2.25 & 2.25 \\
Surfactant & 1.25 & 1.25 & 1.25 & 1.25 \\
Water & 2.75 & 2.75 & 2.60 & 2.60 \\
Isocyanate & 146.1 & 146.1 & 127.3 & 127.3 \\
\hline
\end{tabular}


surface. The compressive strength was measured using a Zwick 1445 instrument.

A TGA analysis was performed with a Q500 analyzer (TA Instruments) using $10 \pm 1 \mathrm{mg}$ of the samples which were heated from 25 to $1000{ }^{\circ} \mathrm{C}$ at a rate of $10^{\circ} \mathrm{min}^{-1}$ under a nitrogen atmosphere. The results were processed using Universal Analysis 2000 software (4.7A version, TA Instruments).

\section{Results and Discussion}

The reactivity of the PUR systems was evaluated by measuring the dielectric polarization, which decreased as an effect of the progress of the reactions and corresponded to temperature profiles [28]. Figure 2 shows the dielectric polarization (a) as a function of the reaction time for all the samples prepared with two types of petrochemical polyols (ETHp, ESTp) and their blends with BIOp.

The PUR system based on ESTp was characterized by the highest reactivity confirmed by the fastest decrease of the dielectric polarization (Fig. 2a), the highest maximum temperature (Fig. 2b) of the reaction mixture during the foaming reaction and reaching the maximum temperature $\left(193{ }^{\circ} \mathrm{C}\right)$ after a shorter reaction time $(264 \mathrm{~s})$. In the case of the PUR system based on ETHp, the maximum temperature was $178^{\circ} \mathrm{C}$. The differences in the reactivity were also confirmed by the foam rise velocity (Fig. 2c).

It is known that a modification of PUR systems with a polyol based on natural oils generally causes lower reactivity during the foaming process and such an effect was confirmed in our earlier studies $[25,29,30]$. An interesting effect was observed in the case of replacing $50 \mathrm{wt} \%$ of the petrochemical polyols by BIOp. The modification of the PUR systems based on the petrochemical polyols with BIOp showed that the changes in the reactivity were more significant in the case of the reaction mixtures based on ESTp. The curves of the dielectric polarization of PU/ETHp and PU/ETHp/BIOp were characterized by similar shapes.

This effect could be associated with the chemical structure of the bio-polyols. The chemical structure of ESTp (Fig. 3c) is more linear than the structure of ETHp (Fig. 3a) and BIOp (Fig. 3b), which are characterized by more steric hindrances (aromatic rings). What is more, ESTp has the lowest functionality and $\mathrm{Mn}$ which can lead to higher mobility of polyol molecules.

The chemical structure of the petrochemical polyol had a significant effect on the cellular structure of the PUR foams as shown in Fig. 4.

The foams based on ESTp were characterized by much larger cells than in the case of the materials based on ETHp. The same tendency was in the case of the PUR systems in which $50 \%$ of the petrochemical polyols had been replaced
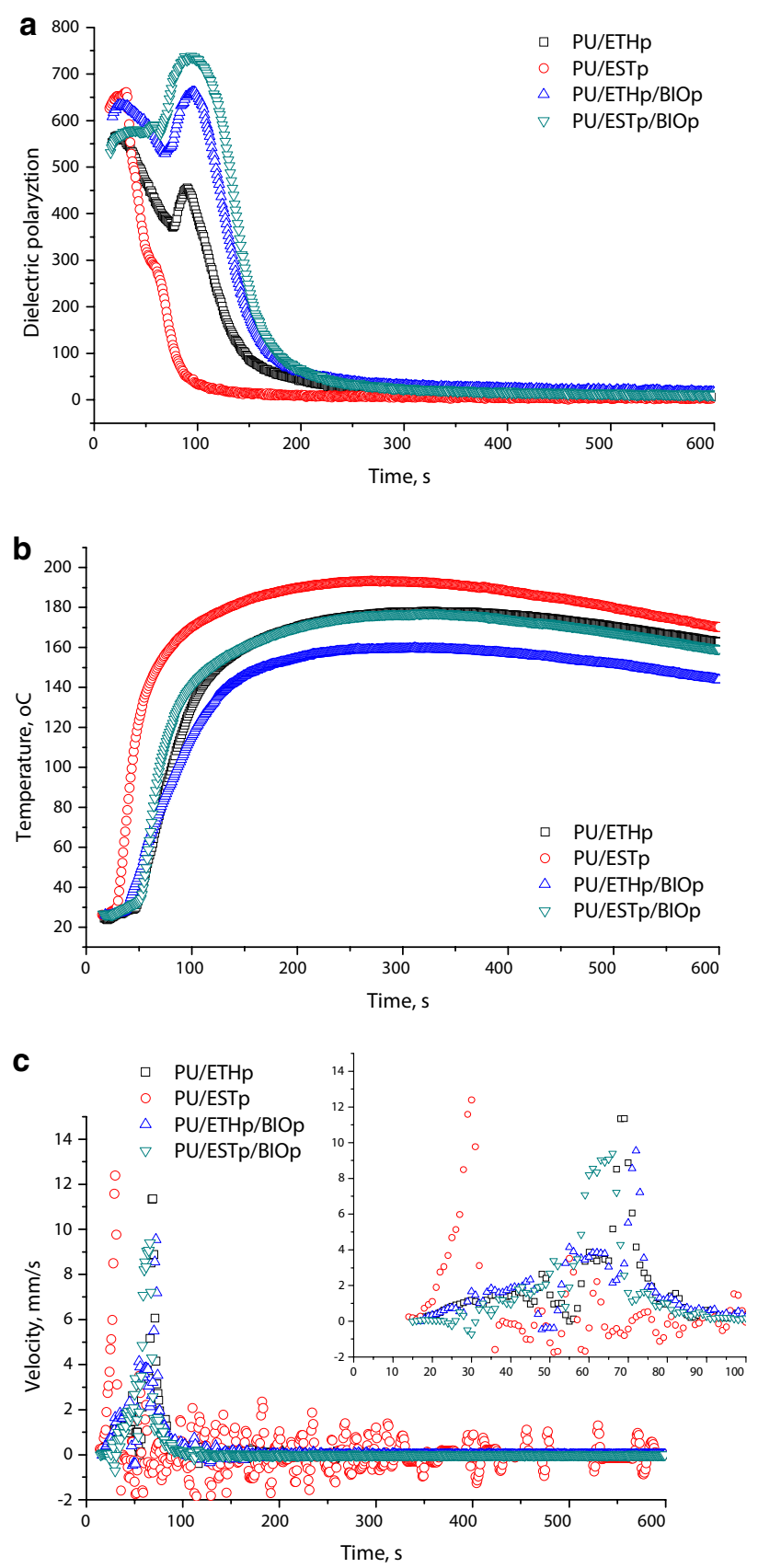

Fig. 2 The influence of the polyol type on the dielectric polarization (a), temperature (b) and foam rise velocity (c) of the reaction mixture during the foaming process

with BIOp. The tendency of the PU/ESTp system to create bigger cells had an important influence on the closed cell content of those foams (Table 3).

The cell opening tendency in the case of PU/ESTp and $\mathrm{PU} / \mathrm{EST} / \mathrm{BIOp}$ can be associated with the high reactivity of the systems and disturbances in the gelling and blowing reactions during the foaming process. In our earlier studies we showed that an introduction of a bio-polyol or a different 


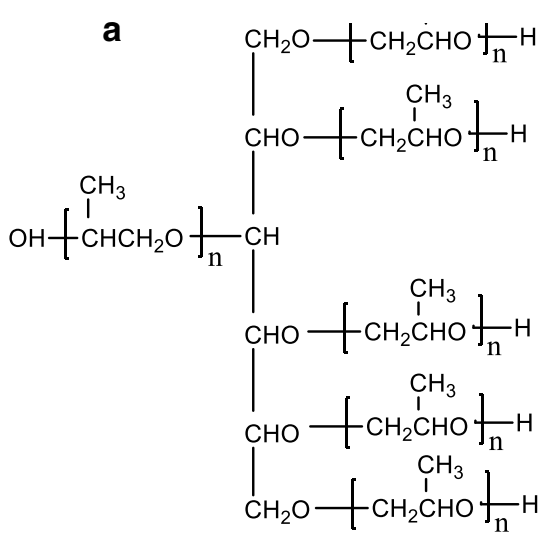

b

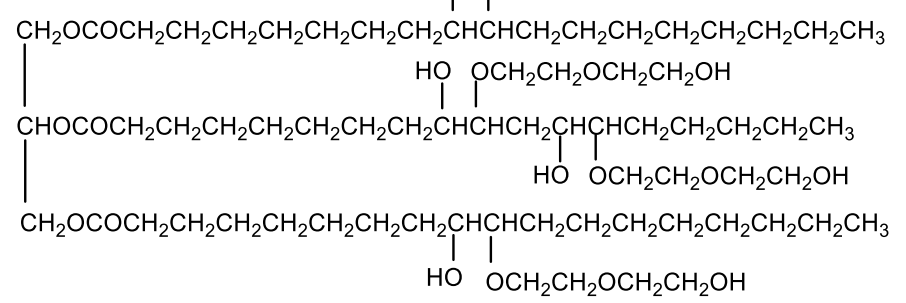

C

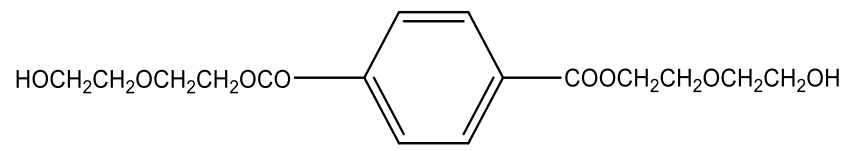

Fig. 3 Schematic chemical structure of: a ETHp, b BIOp and $\mathbf{c}$ ESTp

Fig. 4 The cellular structures of the obtained materials

Table 3 Selected properties of the foams prepared
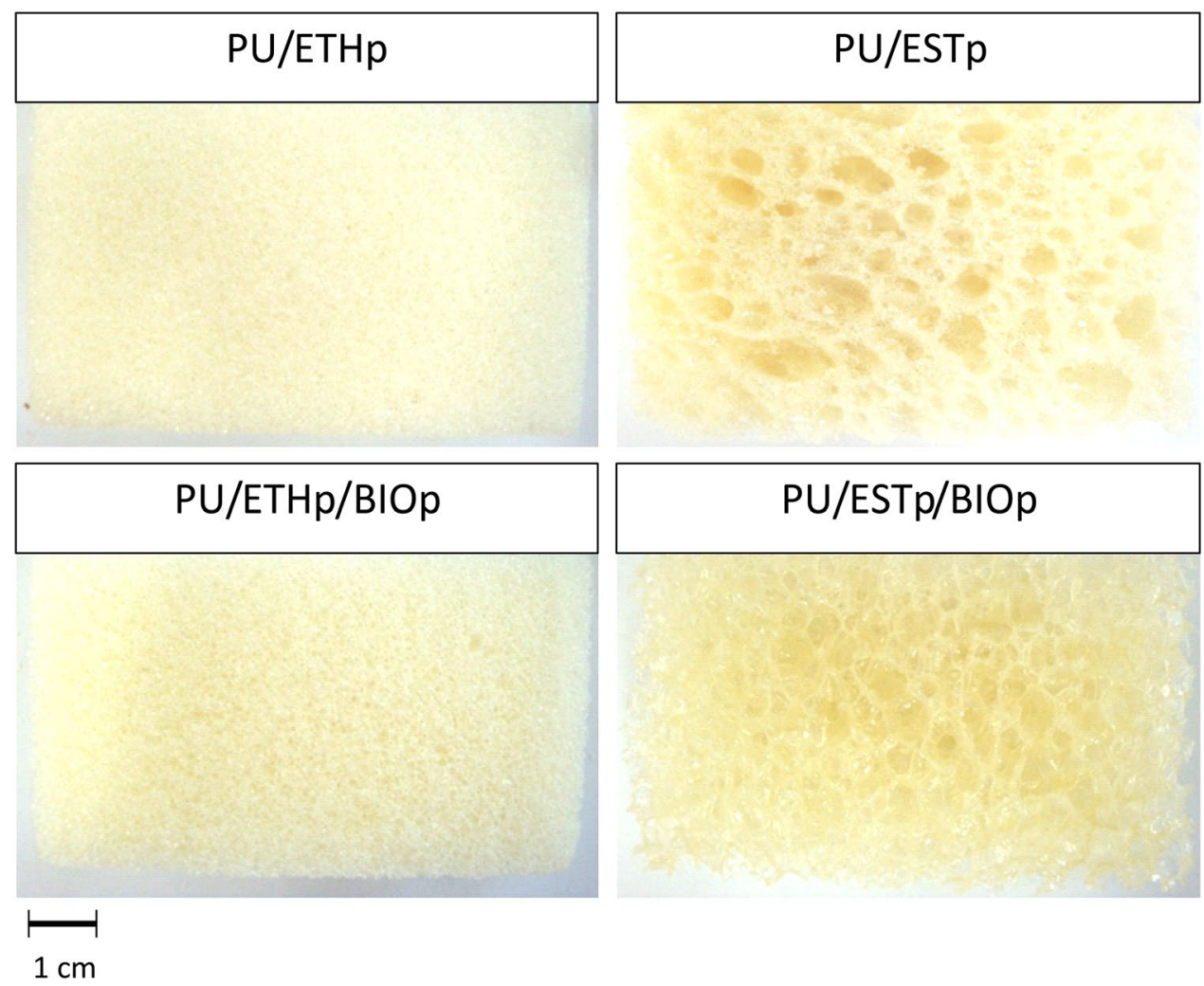

\begin{tabular}{|c|c|c|c|c|c|c|c|c|}
\hline \multirow{3}{*}{$\begin{array}{l}\text { Name of sample } \\
\text { PU/ETHp }\end{array}$} & \multirow{2}{*}{\multicolumn{2}{|c|}{$\begin{array}{l}\text { Content of closed } \\
\text { cells }(\%)\end{array}$}} & \multirow{2}{*}{\multicolumn{2}{|c|}{$\begin{array}{l}\text { Apparent density } \\
\left(\mathrm{kg} / \mathrm{m}^{3}\right)\end{array}$}} & \multicolumn{4}{|c|}{ Compressive strength $(\mathrm{kPa})$} \\
\hline & & & & & \multicolumn{2}{|c|}{ Parallel direction } & \multicolumn{2}{|c|}{$\begin{array}{l}\text { Perpendicular } \\
\text { direction }\end{array}$} \\
\hline & 78.4 & \pm 5.6 & 41.0 & \pm 0.8 & 213.7 & \pm 15.5 & 176.3 & \pm 5.2 \\
\hline PU/ESTp & 7.2 & \pm 3.7 & 59.4 & \pm 2.8 & 387.0 & \pm 3.1 & 305.5 & \pm 14.4 \\
\hline PU/ETHp/BIOp & 73.9 & \pm 3.0 & 41.2 & \pm 0.7 & 185.8 & \pm 22.4 & 172.3 & \pm 11.9 \\
\hline PU/ESTp/BIOp & 8.7 & \pm 1.0 & 53.4 & \pm 5.1 & 152.7 & \pm 9.3 & 163.0 & \pm 15.4 \\
\hline
\end{tabular}


type of fillers to a PUR formulation prolongs the gelling time and disrupts the equilibrium between the foaming and gelling reactions [25, 29-31]. The current study allows a conclusion that too high reactivity of a PUR system also has an influence on the content of closed cells. Too high a temperature for PU/ESTp can cause evaporation of water earlier than carbon dioxide is generated, which can be additionally confirmed by the higher apparent density of the foams based on ESTp (Table 3).

In order to determine the foams' structures more precisely, computer tomography of the materials obtained was performed (Fig. 5). In particular, in the case of the foams based on ESTp, the addition of BIOp led to a more uniform cell structure. In the case of the non-modified foams PU/ ESTp, visible are large pores surrounded be smaller ones and such a cellular structure is non uniform. The presence of different-size pores in this foam is also confirmed by the cell distribution which is shown in Fig. 6. The modification of the foams with the bio-polyols generally caused an increase of the content of small cells. A tendency similar to that in the case of the PU/ESTp foams was also observed for the PU/ETHp foams. However the effect of cell size reduction in the case of PU/ETHp was on a smaller scale due to the more favorable cell structure of the unmodified PU/ETHp foam (Figs. 4, 5, 6).

The apparent density of the porous materials is an important factor which strongly influences their mechanical properties. The effect of the polyol type on the foams' apparent density as well as their compressive strength measured in two directions is shown in Table 3.

The apparent density of the foams based on ESTp was characterized by a higher value despite the same content of water used (as a chemical blowing agent) in each system. It was probably the tendency of the formulation based on ESTp to open cells that caused partial collapse of the foams. Such materials are characterized by a higher apparent density.

The modification of the PU/ESTp system with the biopolyol caused a decrease of the compressive strength value by ca. $50 \%$ in both directions, while such a strong effect was not observed for the materials based on ETHp. This effect could be associated with improper miscibility of ESTp and BIOp.

The compressive strength data have been normalized $\sigma_{\mathrm{n}}$ to the average apparent density of the rigid PUR foams according to Eq. (2) [5]:

$\sigma_{n}=\sigma_{i}\left(\frac{\rho_{\text {average }}}{\rho_{i}}\right)^{2,1}$
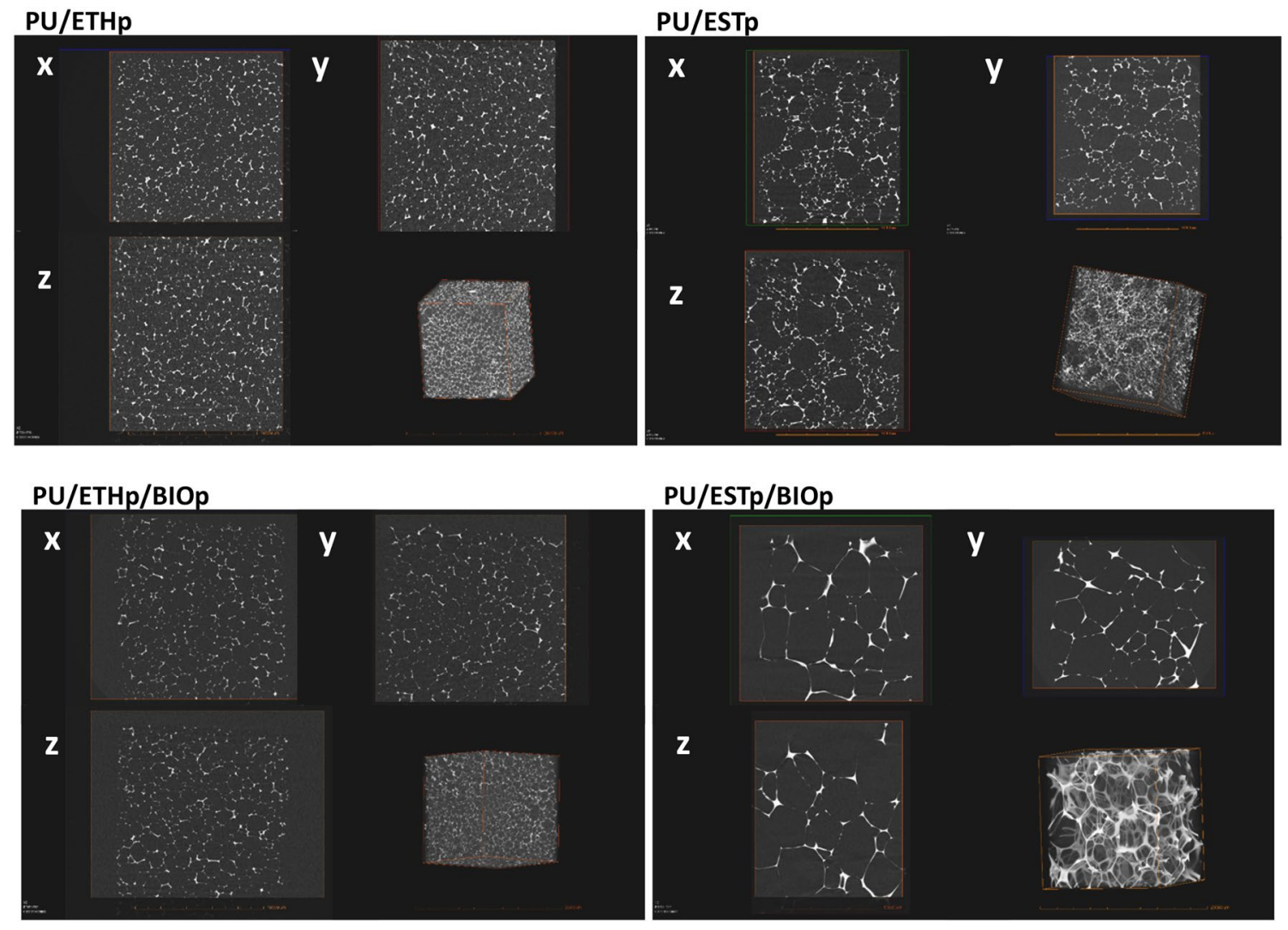

PU/ESTP/BIOp

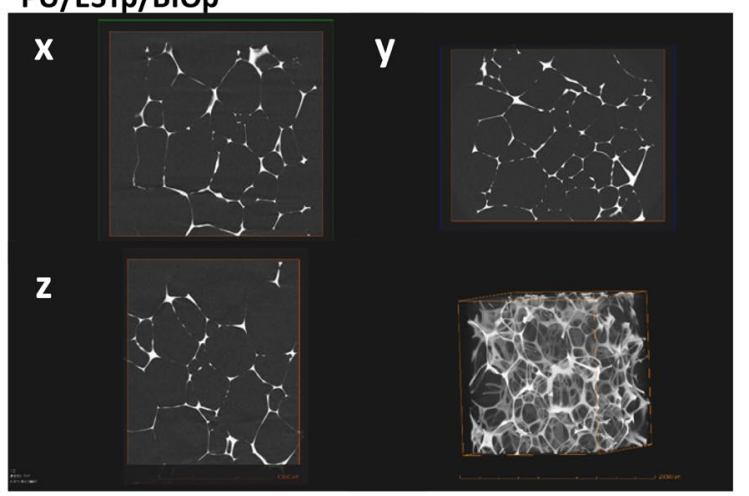

Fig. 5 Images of the porous materials taken at different $2 \mathrm{D}$ orientations $(\mathrm{X}, \mathrm{Y}, \mathrm{Z})$ and in $3 \mathrm{D}$ 

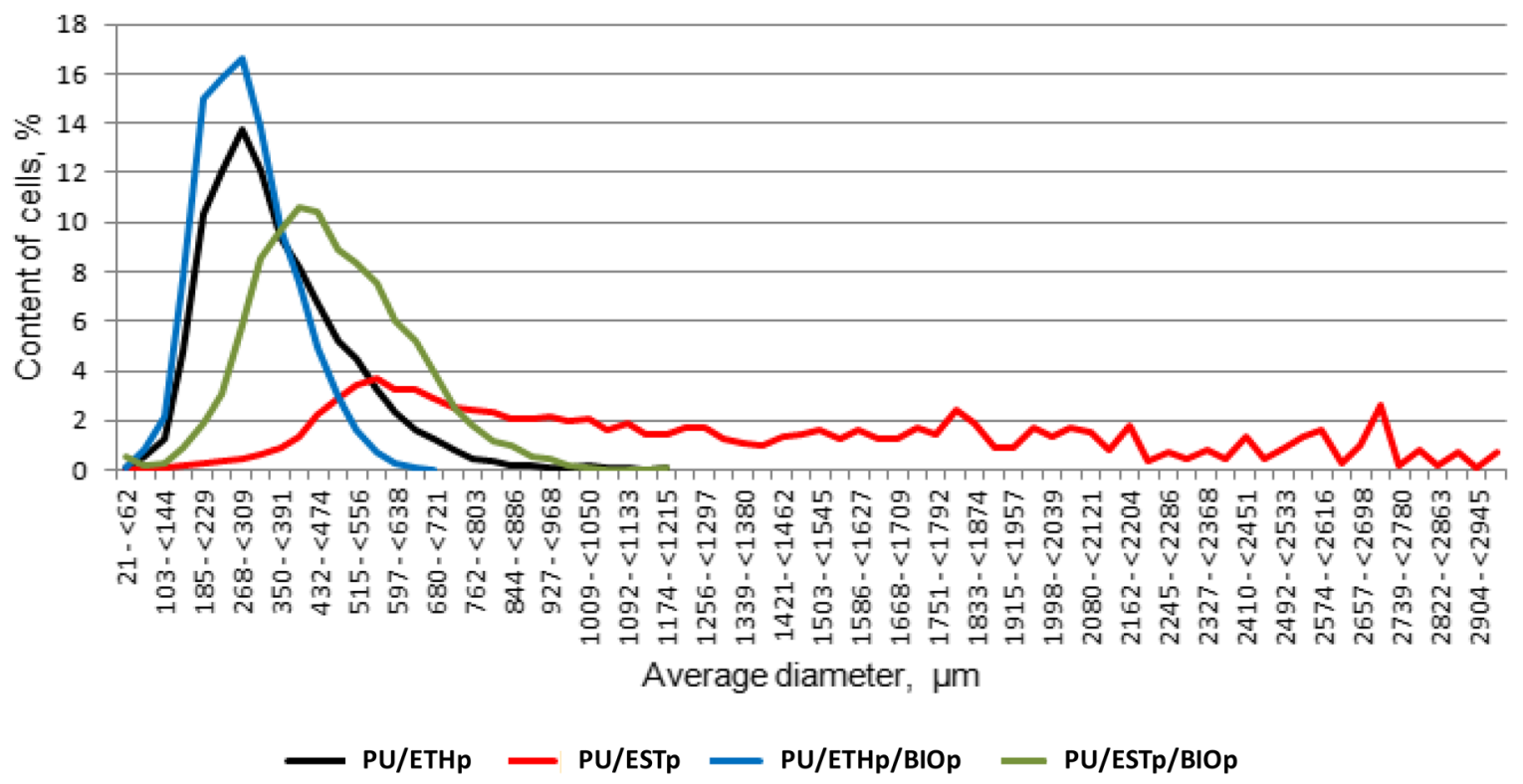

PU/ETHp/BIOp

PU/ESTp/BIOp

Fig. 6 The pore size distribution in the foam samples

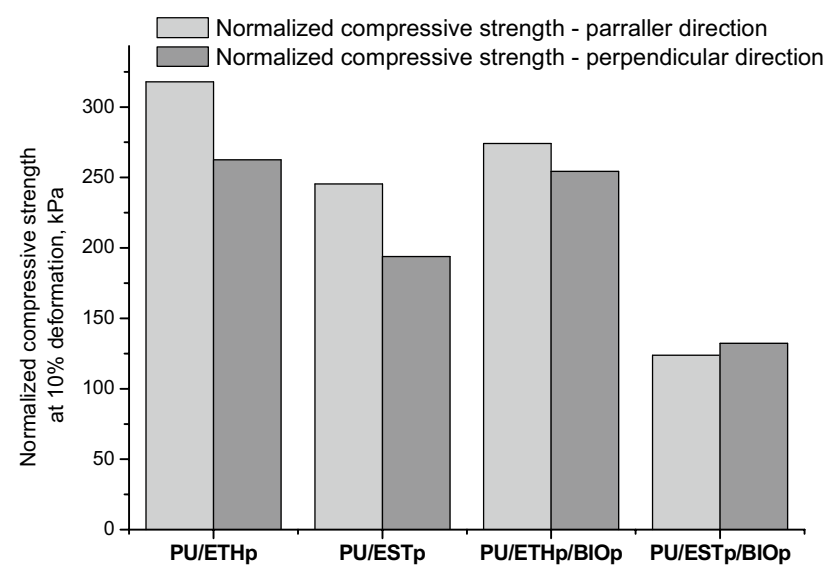

Fig. 7 The compressive strength of the rigid PUR foams. The data, taking into account the apparent density of foams, were normalized according to [5]

where, $\sigma_{\mathrm{i}}$ is the experimental raw strength of a given foam determined from the stress-strain curve, $\rho_{\mathrm{i}}$ is the apparent density of the same foam, and $\rho_{\text {average }}$ is the average apparent density calculated on the basis of the compared foam densities.

The normalized data of the foam compression strengths after the calculation according to formula (2) are shown in Fig. 7.

The normalized data of the compressive strength show that the highest compressive strength corresponds to the foams based on ETHp, and that the modification with the bio-polyol of the PUR formulation based on ETHp did not give a significant effect. This is associated with a more regular cellular structure of PU/ETHp and PU/ETHp/BIOp than in the foams based on PU/ESTp.

The thermal degradation of both types of the petrochemical and the bio polyols as well as the PUR foams was investigated using a thermogravimetric analysis including both the mass change (TG) and the derivative of the mass change (DTG) curves, which are shown in Figs. 8, 9 respectively.

Changes in the mass loss of the polyols start at temperatures below $100{ }^{\circ} \mathrm{C}$ and this is an effect of water evaporation as well as of volatile impurities. Decomposition of urethane bonds starts at an average temperature of $260{ }^{\circ} \mathrm{C}$ [32], however in the case of the PUR materials investigated in the experiment the beginning of the decomposition is observed at temperatures below $250{ }^{\circ} \mathrm{C}$ (Fig. 9). The PUR materials based on the ESTp and BIOp polyols have similar decomposition curves. The derivative TG curves of the materials reveal actually one (PU/ETHp) or two (PU/ESTp, PU/ ETHp/BIOp and PU/ESTp/BIOp) main degradation steps. The character of the loss rate curves in the temperature range $300-350{ }^{\circ} \mathrm{C}$ for the ETHp polyol and the respective PU/ ETHp foam is similar, while in the case of the other foams the degradation process is delayed due to better thermal stability of both the ESTp and BIOp polyols.

In the case of the PU/ETHp/BIOp foam, an effect of higher stability due to replacing $50 \mathrm{php}$ of ETHp with BIOp was disclosed in the range of temperatures $350-450{ }^{\circ} \mathrm{C}$. The thermal stability of PU/ESTp/BIOp seems to be the highest based on the highest temperature of the maximum loss rate (Fig. 9), which is slightly higher comparing to the respective temperature for the PU/ESTp sample. 
Fig. 8 TG curves of the polyols and the PUR foams obtained with different types of polyols

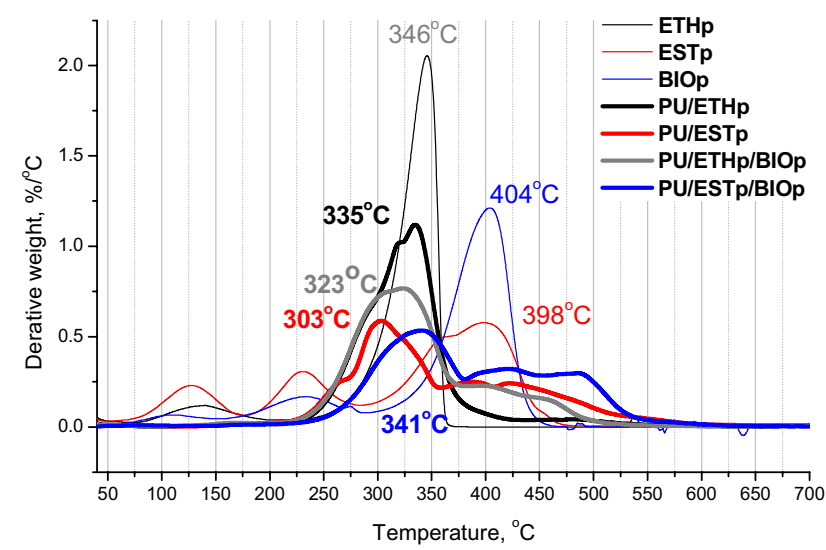

Fig. 9 DTG curves of the polyols and the PUR foams obtained with different types of polyols

It is known that polyols containing ether linkages in their molecules are less thermally stable than those with ester linkages, such as vegetable oil-based polyols [33]. PUR foams based on ESTp, which contains aromatic rings in its structure, are thermally more stable than foams from aliphatic polyols [34].

The second step of the decomposition process occurs at ca. $350-550{ }^{\circ} \mathrm{C}$ and this is related mainly to the decomposition of the polyols and aromatic moieties [18]. BIOp is characterized by long chains which come from fatty acids present in the molecules of the modified vegetable oil and such a chemical structure can increase the thermal stability of this component.

\section{Conclusions}

It can be concluded that the structure of a polyol has a significant effect on the reactivity and properties of rigid polyurethane foams. The applied polyester polyol was more reactive comparing to the polyether polyol. The replacement

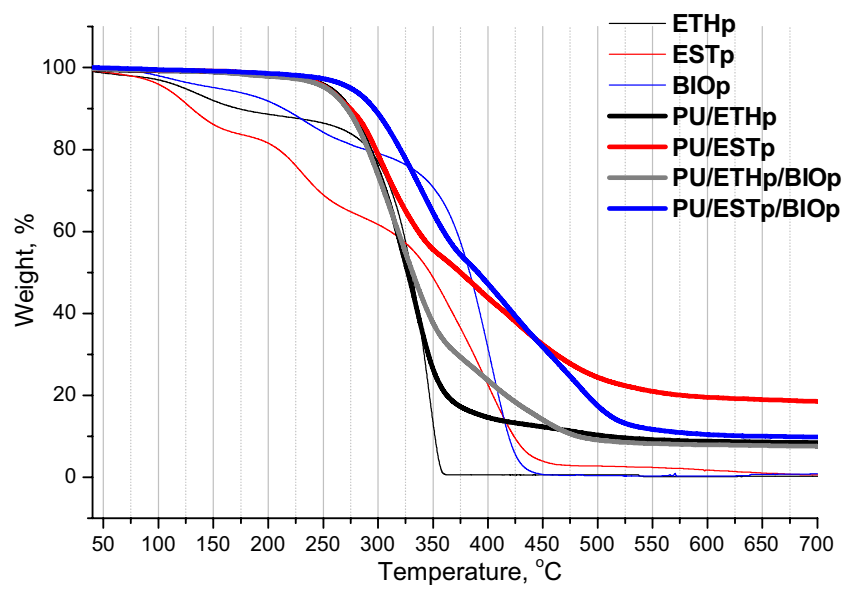

of a part of both types of the petrochemical polyols with a bio-based polyol decreased the reactivity of the reaction mixtures. However, a more significant effect was observed for the polyurethane systems with the polyester polyol.

It was shown that the type and reactivity of the petrochemical polyol had a significant influence on the foaming process and a tendency of the polyurethane system to exhibit cell opening. The content of closed cells was reduced from ca. $80 \%$ in the case of the foams based on the polyether polyol to $10 \%$ for the foams obtained using the polyester polyol. In the case of the foams based on the polyether polyol modified with the bio-polyol, such a significant effect was not observed.

It was noticed that an addition of a bio-polyol into the foam systems caused a reduction of the cell size regardless of the type of the petrochemical polyol used. In the case of both the foams modified with the bio-polyol, the cell size distribution was comparable.

An important decrease (ca. 50\%) of the compressive strength of the foams based on the polyester polyol took place as a result of the modification of the polyurethane system with the bio-polyol, whereas such a modification of the polyether polyol-based system practically did not cause changes in the foam's mechanical properties. Replacing the polyester polyol with the bio-polyol in the polyurethane system improved the thermal stability of the modified foams.

Acknowledgements The study has been financed by the National Research and Development Centre within the framework of the project EPURNAT PBS1/B5/18/2012.

Open Access This article is distributed under the terms of the Creative Commons Attribution 4.0 International License (http://creativeco mmons.org/licenses/by/4.0/), which permits unrestricted use, distribution, and reproduction in any medium, provided you give appropriate credit to the original author(s) and the source, provide a link to the Creative Commons license, and indicate if changes were made. 


\section{References}

1. Mosiewicki MA, Aranguren MI (2013) Eur Polym J 49:1243

2. Barczewski M, Matykiewicz D, Piasecki A, Szostak M (2018) Compos Interfaces 25:287

3. Salasińska K, Barczewski M, Górny R, Kloziński A (2018) Polym Bull 75:2511

4. Formela K, Hejna A, Zedler Ł, Przybysz M, Ryl J, Reza Saeb M, Piszczyk Ł (2017) Ind Crop Prod 108:844

5. Kurańska M, Prociak A, Cabulis U, Kirpluks M (2015) Polimery 60:705

6. Paberza A, Cabulis U, Arshanitsa A (2014) Polimery 59:477

7. Li H, Mahmood N, Ma Z, Zhu M, Wang J, Zheng J, Yuan Z, Wei Q, Xu C (2017) Ind Crop Prod 103:64

8. Gaidukova G, Ivdre A, Fridrihsone A, Verovkins A, Cabulis U, Gaidukovs S (2017) Ind Crop Prod 102:133

9. Agrawal A, Kaur R, Walia RS (2017) Eur Polym J 95:255

10. Parcheta P, Datta J (2017) Crit Rev Environ Sci Technol 47:1986

11. Fridrihsone-Girone A, Stirna U, Misane M, Lazdina B, Deme L (2016) Prog Org Coat 94:90

12. Auguścik M, Kurańska M, Prociak A, Karalus W, Lipert K, Ryszkowska J (2016) Polimery 61:490

13. Fridrishohe-Girone A, Stirna U (2014) Polimery 59:333

14. Narine SS, Yue J, Kong X (2007) J Am Oil Chem Soc 84:173

15. Petrovic ZS (2008) Polym Rev 48:109

16. Sharma C, Kumar S, Raman UA, Aswal VD, Rath SK, Harikrishnan G (2014) J Appl Polym Sci 131:17

17. Kirpluks M, Cabulis U, Kurańska M, Prociak A (2013) Key Eng Mater 559:69

18. Stirna U, Fridrihsone A, Lazdin B, Misane M, Vilsone D (2013) J Polym Environ 21:952

19. Cabulis U, Sevastyanova I, Andersons J, Beverte I (2014) Polimery 59:207
20. Kirpluks M, Cabulis U, Ivdre A, Kuranska M, Zieleniewska M, Auguscik M (2016) J Renew Mater 4:86

21. Pietrzak K, Kirpluks M, Cabulis U, Ryszkowska J (2014) Polym Degrad Stabil 108:201

22. Prociak A, Kurańska M, Cabulis U, Kirpluks M (2017) Polym Test 59:478

23. Zlatanic A, Petrovic ZS, Dusek K (2002) Biomacromolecules $3: 1048$

24. Zhang C, Kessler MR (2015) ACS Sustain Chem Eng 3:743

25. Kurańska M, Prociak A (2016) Ind Crop Prod 89:182

26. Kurańska M, Prociak A, Kirpluks M, Cabulis U (2015) Ind Crop Prod 74:849

27. Kurańska M, Prociak A, Cabulis U, Kirpluks M, Ryszkowska J, Auguścik M (2017) Ind Crop Prod 95:316

28. Paruzel A, Michałowski S, Hodan J, Horak P, Prociak A, Benes H (2017) ACS Sustain Chem Eng 5:6237

29. Marcovich NE, Kurańska M, Prociak A, Malewska E, Bujok S (2017) Polym Int 66:1522

30. Marcovich NE, Kurańska M, Prociak A, Malewska E, Kulpa K (2017) Ind Crop Prod 102:88

31. Kurańska M, Prociak A, Michałowski S, Cabulis U, Kirpluks M (2016) Polimery 9:625

32. Javni I, Petrovic ZS, Guo A, Fuller R (2000) J Appl Polym Sci 77:1723

33. Guo A, Javni I, Petrovic Z (2000) J Appl Polym Sci 77:467

34. Paberza A, Fridrihsone-Girone A, Abolins A, Cabulis U (2015) Polimery 60:872

Publisher's Note Springer Nature remains neutral with regard to jurisdictional claims in published maps and institutional affiliations. 